Word count (excl. references: 6690)

\title{
Business models and supply chains for the Circular Economy
}

\author{
Martin Geissdoerfer ${ }^{1,2,}$, Sandra Naomi Morioka ${ }^{3}$, Marly Monteiro de Carvalho ${ }^{3}$, Steve \\ Evans $^{1}$ \\ ${ }^{1}$ Institute for Manufacturing, Engineering Department, University of Cambridge, 17 Charles \\ Babbage Road, Cambridge, CB3 OFS, United Kingdom, \\ ${ }^{2}$ Garwood Center for Corporate Innovation, Haas School of Business, University of \\ California, Berkeley, Berkeley, CA 94720-1930, United States of America \\ ${ }^{3}$ Production Engineering of Polytechnic School, University of São Paulo, Av. Prof. Almeida \\ Prado, 128 Tr.2 Biênio 2o. andar, São Paulo, SP, 05508-900, Brazil \\ *Email:ml733@cam.ac.uk \\ Journal of Cleaner Production (author's version) \\ https://doi.org/10.1016/j.jclepro.2018.04.159 \\ Free Elsevier Sharelink: https://authors.elsevier.com/c/1Wyeb3QCo9R1Yx
}

\section{Highlights}

- The Circular Economy is gaining importance as a possible solution to address sustainable development in academia, industry, and policy

- Based on literature analysis and four case studies, this paper proposes a framework to integrate circular business models and circular supply chain management in a way that fosters sustainable development

- The proposed framework shows how different circular business models are driving circular supply chains in different loops: closing loops, slowing loops, intensifying loops, narrowing loops, and dematerialising loops

- The identified circular business models vary in complexity of the circular supply chain and in the value proposition.

- The framework reinforces the CBM's conditions for sustainability: economic, environmental and social goals, proactive stakeholder management, long-term perspective. The research indicates circular business and circular supply chain help in realising sustainability ambitions. 


\begin{abstract}
The Circular Economy is increasingly seen as a possible solution to address sustainable development. An economic system that minimises resource input into and waste, emission, and energy leakage out of the system is hoped to mitigate negative impacts without jeopardising growth and prosperity. This paper discusses the sustainability performance of the circular business models (CBM) and circular supply chains necessary to implement the concept on an organisational level and proposes a framework to integrate circular business models and circular supply chain management towards sustainable development. It was developed based on literature analysis and four case studies. The proposed framework shows how different circular business models are driving circular supply chain in different loops: closing loops, slowing loops, intensifying loops, narrowing loops, and dematerialising loops. The identified circular business models vary in complexity of the circular supply chain and in the value proposition. Our research indicates circular business and circular supply chain help in realising sustainability ambitions.
\end{abstract}

Keywords: circular business models, circular supply chain, sustainable business models, sustainable development, circular economy; business model innovation.

\title{
1. Introduction
}

Sustainable development aims at satisfying current needs without harming future generations' ability to satisfy their needs (WCED 1987), while considering limitations in the Earth's resources in face of human development (Meadows et al. 1972; Meadows, Randers, and Meadows, 2004), as well as synergies and trade-offs between economic, environmental and social goals (Elkington 1997). Based on the preceding Millennium Goals, the United Nations proposed 17 sustainable development goals (SDG's), to be achieved by, 2030, including issues related to poverty, gender equality, sustainable cities, amongst others (United Nations, 2015).

In order to address sustainable development, the concept of the Circular Economy is gaining traction and is increasingly seen as a complete or partial solution to these challenges (Geissdoerfer et al., 2017a). With an economic system that minimises resource input into and waste, emission, and energy leakage out of the system, it is hoped that environmental impact can be reduced, without jeopardising growth and prosperity (Bakker et al., 2014; European Commission, 2014; Evans, 2009; Webster, 2015). The origins of the concept of Circular Economy is said to have been introduced by David Pearce in 1990 by Andersen (2007) and Su et al. (2013). The concept was addressing the relationships between the four economic functions of the environment, consisting in amenity values, its function as a resource base and a sink for economic activities, and its role as a life-support system. However, Stahel (1982) might have introduced the concept earlier, talking of a self-replenishing system that minimizes 
material and energy input as well as environmental deterioration without negative influences on growth and progress.

The circular economy is based on the idea of putting private business into the service of the transition to a more sustainable system. As the singular actor with the most resources and capabilities, companies could considerably advance this transition by creating additional value with an extended and more proactively managed stakeholder network (Geissdoerfer, Bocken, and Hultink, 2016; Porter and Kramer, 2011; Nidumolu, Prahalad, and Rangaswami, 2009). Especially the concept of Failed Value Exchanges is decisive in this context; it assumes that by realising value that is either missed, destroyed, not internalised, or not offered despite existing demand in the market, organisations can potentially benefit society while at the same time gaining competitive edge (Yang et al., 2016).

We and other authors (Chesbrough and Rosenbloom, 2002; Doleski, 2015; KnyphausenAufsess and Meinhardt, 2002; Osterwalder and Pigneur, 2013) consider business model innovation as a key tool to implement these changes into organisations because of the concept's usefulness in analysing, structuring, planning, and communicating in face of the increasing complexity of organisational configurations and activities (Doleski, 2015; KnyphausenAufsess and Meinhardt, 2002).

The business model concept became popular in the 1990s with the emergence of new revenue mechanism accompanying the emergence of e-commerce (Magretta, 2002; Osterwalder and Pigneur, 2005; Zott et al., 2011). In this context, it was initially used to pitch simplified but comprehensive business ideas to investors within a short time frame (Knyphausen-Aufseß and Meinhardt, 2002). Several authors have defined the concept differently and there have been comprehensive reviews of these definitions to come up with a unified understanding (such as Evans et al., 2002; Schallmo, 2013; Zott et al., 2011). On the basis of these comparative approaches, we define business model as simplified representations of the elements of a complex organisational system and the interrelation between these elements. It determines the organisation's value proposition, value creation and delivery, and value capturing and aims at analysis, planning, and communication in face of increasing complexity. The organisational environment and value network is also considered to different degrees in most approaches (Geissdoerfer et al., under review).

Combining the challenges of putting Circular Economy into reality and the practice-oriented approach of business model innovation leads to the concept of circular business models (CBM), a term used to describe business models that are suited for the Circular Economy by incorporating elements that slow, narrow, and close resource loops, so that the resource input into the organisation and its value network is decreased and waste and emission leakage out of the system is minimised (Bocken et al., 2016). As we lay out in the following section, we would add an emphasis on the linkage between CBM and circular supply chain management (CSCM) towards closed loops in different approaches as closing loops, slowing loops, intensifying loops, narrowing loops, and dematerialising loops. intensifying and dematerialising loops. 
The arguably biggest difference between conventional business models and those designed for the Circular Economy lies in their value creation and delivery element, and here particularly in the supply chain. We use the term circular supply chain management (CSCM), which comprises the configuration and coordination of the supply chain to close, narrow, slow, intensify and dematerialise resource loops. Despite the importance of CSCM for CBMs and therefore for the implementation of the Circular Economy, it remains a rather unexplored area of research (Homrich et al., 2017). Moreover, it is important to contextualize CSCM with other related but not the same concepts like sustainable supply chain management (SSCM) (Wu and Pagell, 2011) or green supply chain management (GSCM) (Zhu and Sarkis, 2004), in which the closed loops are not a core issue. in order to contribute to the nascent knowledge about CSCM and add insights from industry on CBM, the present research aims to propose a framework to integrate circular business models and circular supply chain management towards sustainable development. To address this goal, four case studies are presented, Alpha, an office furniture remanufacturer, Beta, a high recycled content flat aluminium sheet manufacturer, Gama designs and produces luxurious fashion accessories from fire hoses, and Delta provides a bike sharing service. This paper is structured in the following way. First, the research's background is illustrated (Section 2), before we explain the applied research method (Section 3). This is followed by a presentation (Section 4) and a subsequent discussion of the findings (Section5). The paper ends with a conclusions and outlook section (Section 6).

\section{Literature background}

This section introduces the two key concepts underlying this research, circular business models (CBM) and circular supply chains (CSC), and illustrates their role in sustainable development.

\subsection{Circular business models}

The modern understanding of the Circular Economy is based on different schools of thought, like Cradle to Cradle (McDonough and Braungart, 2002), Laws of Ecology (Commoner 1971), Looped and Performance Economy (Stahel, 2010), Regenerative Design (Lyle 1994), Industrial Ecology (Graedel and Allenby 1995), Biomimicry (Benyus, 2002), or the Blue Economy (Pauli, 2010). The circular economic system avoids waste and tries to preserve the inherent value of products as long as feasible (European Commission, 2014). The goal of this is to minimise the consumption of resources by recycling materials and/or energy after the use phase to avoid leakage out of the system (Ellen MacArthur Foundation, 2013). The butterfly diagram focus on the biological and technical closed loops as a continuous flow of materials through the value circle, without focusing on one particular circular loop but in the understanding of how these loops work (Ellen MacArthur Foundation, 2013).

To utilise the sustainable business model's analytical, strategic, and communicational potential to integrate sustainability considerations on the organisational level, three mayor elements have to be added: sustainable value creation, more pro-active management of a more comprehensive set of stakeholders, and a long-term perspective (Geissdoerfer et al., 2016; 2017b; under review). We synthesise this from an increasing range of definitions of the SBM concept in the literature. These key definitional elements can be found, among others, in the definitions of 
Boons et al. (2013), who addresses not only the creation of superior customer value but also private and public societal benefits; Schaltegger et al. (2012), who highlights customer and social value, economic advantages, and the mitigation of social and environmental concerns, Stubbs and Cocklin (2008), who emphasises the cooperation with a broad range of stakeholders. and Evans, Rana, and Short (2014), who focus on both the creation of social, environmental, and economic value for and the alignment of interests of a broader set of stakeholders that is going beyond the monetary value for customers and shareholders that 'unsustainable' business models would aim at.

Following Bocken et al. (2013), we consider business models for the circular economy as a class of or generic strategy for sustainable business models. By closing, narrowing, slowing, intensifying, and dematerialising loops, the resource inputs into and the waste and emission leakage out of the organisational system are minimised, and, consequently, the sustainability performance improved. Closing, narrowing, and slowing loops (Bocken et al., 2016) refer to the biological and technical nutrition cycles of the Circular Economy (Ellen MacArthur Foundation, 2012), and comprises recycling measures (closing), efficiency improvements (narrowing), and use phase extensions (slowing or extending). Although considered in the original concept as part of slowing loops, we want to emphasise the importance of a more intense use phase (intensifying), and add the substitution of product utility by service and software solutions (dematerialising) to our conceptualisation.

Consequently, as illustrated in Figure 1, CBMs can be defined as SBMs - which are business models that aim at solutions for sustainable development by creating additional monetary and non-monetary value by the pro-active management of a multiple stakeholders and incorporate a long-term perspective - that are specifically aiming at solutions for the Circular Economy through a circular value chain and stakeholder incentive alignment. 


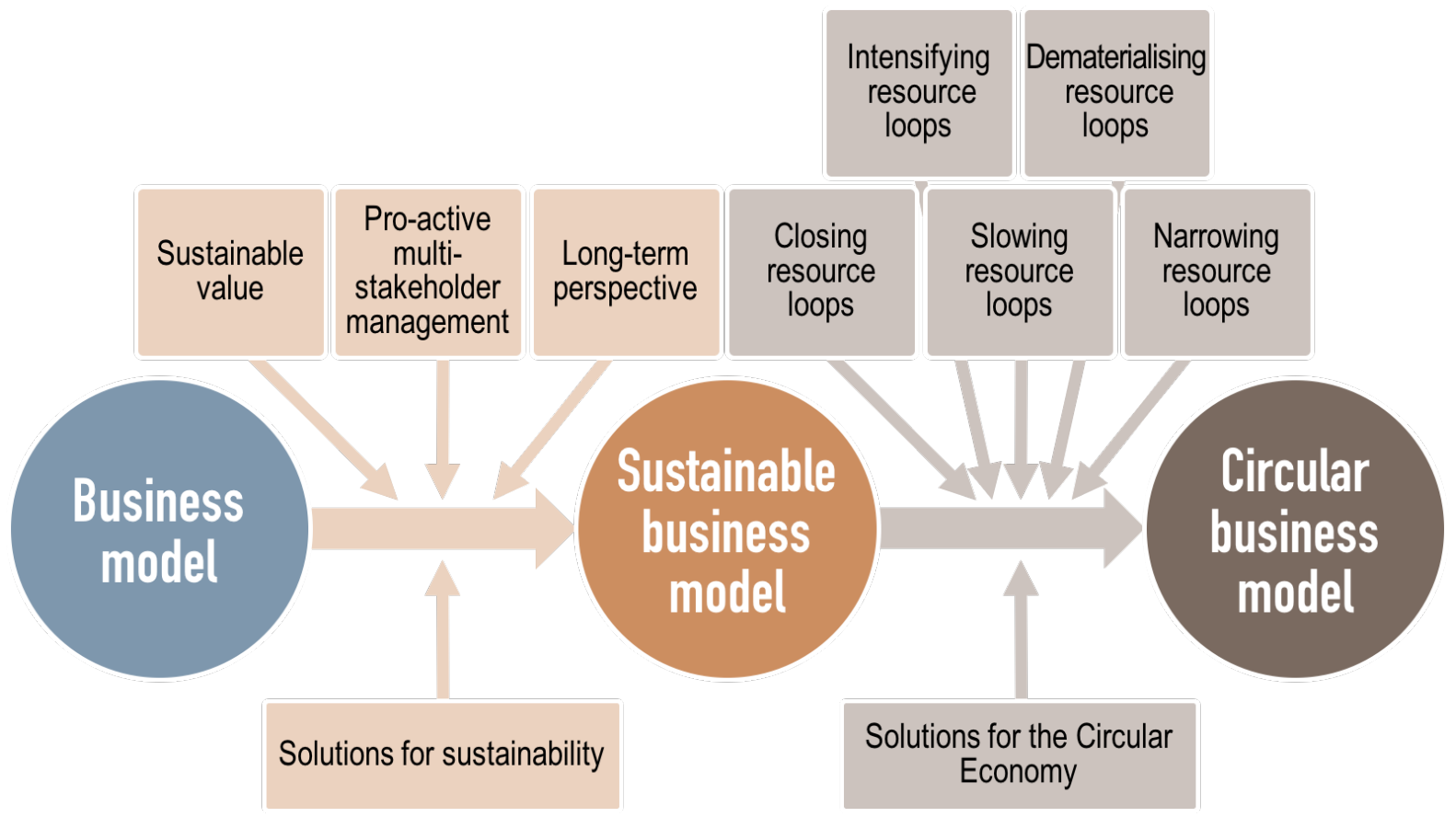

Figure 1. Comparison of traditional, sustainable, and circular business models

Figure further explores this correlation by contrasting circular (C) and linear (L) configurations of the value proposition, value creation and delivery, and value capture element of a business model with its economic, environmental, and social performance, providing an example of each item, as well as a possible manifestation in an office furniture manufacturing operation. In this paper, it is argued that all three elements of a business model (value proposition, value creation and delivery, and value capture (Richardson, 2008)) have to 'go circular' to achieve optimal sustainability performance within the Circular Economy. 


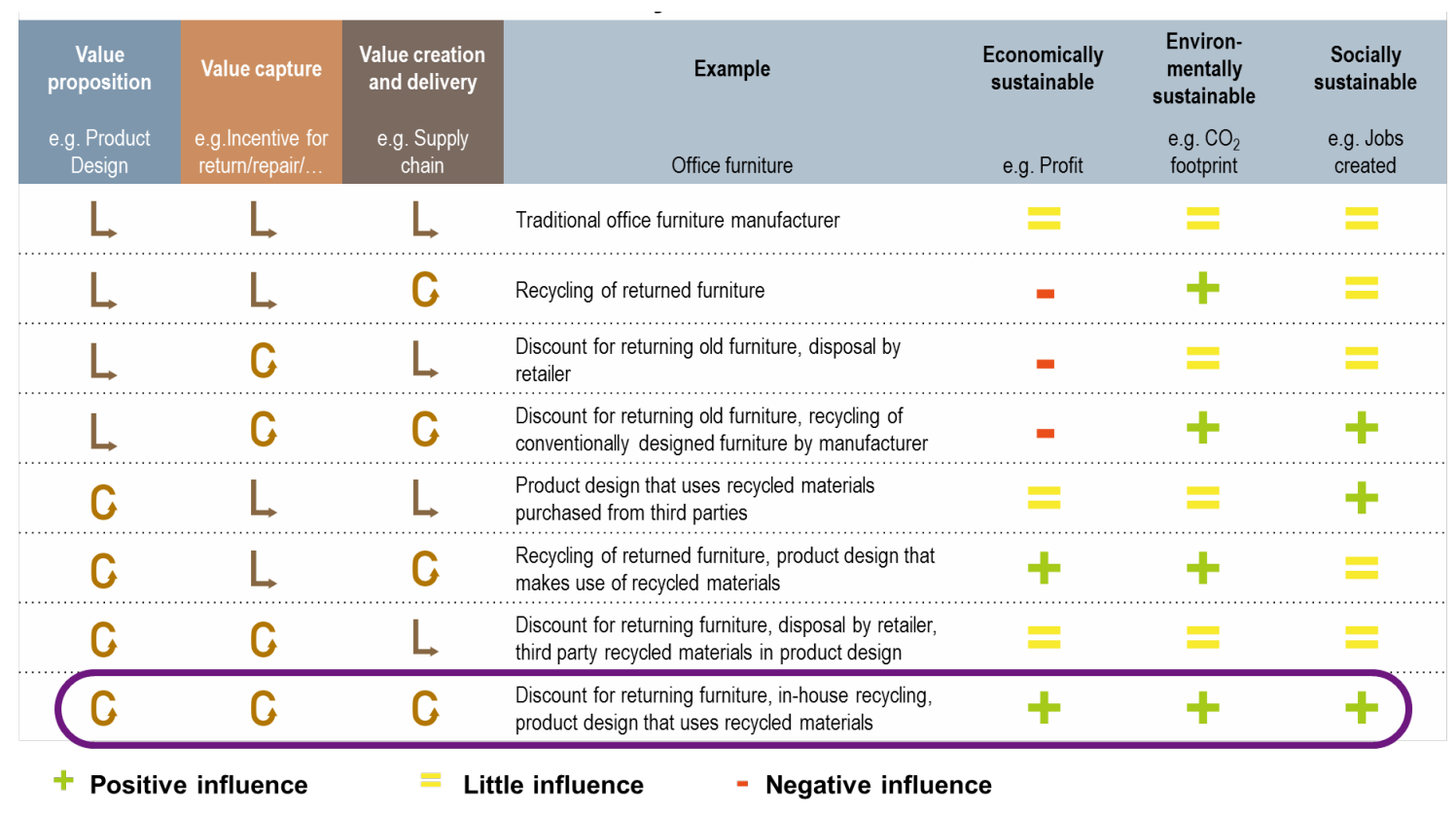

Figure 2. A value based view on the sustainability of circular business models.

To further argue about the integration between CBM and sustainability, Table 1 indicates how each business model element (value proposition, creation and delivery system and value capture) is affected by economic, environmental, social dimensions and a long-term orientation, which are four core issues of corporate sustainability (Lozano, 2008). Regarding value proposition, the core goal and vision of the organization translated into offerings (products and services) need to ensure revenue to compensate direct and indirect costs, to be designed according to approaches such as eco-design and design for disassembly, to ensure society wellbeing, and finally to guarantee long-term capacity to address economic, environmental and social concerns. In terms of value creation and delivery system for CBM, it is critical to develop a value network with stakeholders that are motivated by and contribute to economic viability, environmental benefits, social concerns and preparation for long-term challenges of businesses associated. Finally, value captured by the system associated with $\mathrm{CBM}$ includes not only economic one, but also natural resource preservation and society wellbeing both in the short and in the long-term.

Table 1. Deployment of sustainability dimensions into circular business models

\begin{tabular}{clll}
\hline \multirow{2}{*}{$\begin{array}{c}\text { Sustainability } \\
\text { dimensions }\end{array}$} & Value proposition & $\begin{array}{c}\text { Value creation and } \\
\text { delivery system }\end{array}$ & Value capture \\
\cline { 2 - 4 } Economic & $\begin{array}{l}\text { Offerings (products and } \\
\text { services) with economic } \\
\text { margin to ensure profit }\end{array}$ & $\begin{array}{l}\text { Incentives for actors in the } \\
\text { supply chain to extend } \\
\text { product use and return } \\
\text { disposal to the value system }\end{array}$ & $\begin{array}{l}\text { Profit (or at least not } \\
\text { negative result) to each } \\
\text { stakeholder }\end{array}$ \\
\hline
\end{tabular}




\begin{tabular}{clll}
\hline Environmental & $\begin{array}{l}\text { Products and services } \\
\text { designed to minimize } \\
\text { natural resources depletion }\end{array}$ & $\begin{array}{l}\text { Eco-efficient production } \\
\text { and logistic operations }\end{array}$ & $\begin{array}{l}\text { Reduced environmental } \\
\text { burden by extracting more } \\
\text { value from less natural } \\
\text { resource consumption }\end{array}$ \\
Social & $\begin{array}{l}\text { Maximize product and } \\
\text { service value for society } \\
\text { well-being }\end{array}$ & $\begin{array}{l}\text { Pro-active approach } \\
\text { towards stakeholders in the } \\
\text { closed loops }\end{array}$ & $\begin{array}{l}\text { Further environmental } \\
\text { consciousness on the value } \\
\text { of products }\end{array}$ \\
$\begin{array}{c}\text { Protection of } \\
\text { future }\end{array}$ & $\begin{array}{l}\text { Long-term capacity to } \\
\text { address economic, } \\
\text { environmental and social } \\
\text { concerns }\end{array}$ & $\begin{array}{l}\text { Incremental and radical } \\
\text { changes in the system level } \\
\text { to ensure long-term } \\
\text { partnerships }\end{array}$ & $\begin{array}{l}\text { Preparation of current } \\
\text { production systems to be } \\
\text { make "perfect" circular } \\
\text { economy viable in the } \\
\text { future }\end{array}$ \\
\hline
\end{tabular}

\subsection{Circular supply chain management}

The term supply chain management (SCM) was first coined by Oliver and Webber in 1982 (Christopher, 2016; Stadtler et al., 2015), and interest in the topic has rapidly increased ever since (Cooper and Ellram 1993). Today, the topic is researched by a broad range of disciplines, from operations management to psychology (Burgess et al., 2006), resulting in a body of literature in excess of 40,000 journal articles and books (Asgari et al., 2016). As a consequence, there is hardly any periodical on marketing, manufacturing, distribution, customer management, or transportation that does not contain one or more articles in the field (Ross 1998).

This immense interest in SCM, combined with narrow silos of knowledge of the different disciplines and organisational functional units, and the broad diversity of employed research methodology (Burgess et al., 2006) lead to a broad range of definitions and understandings of the topic (see e.g. New 1997; Lummus et al., 2001; Mentzer et al., 2001; Kauffman, 2002). Based on these definitions and the review articles illustrated in Table 1, we define SCM as the configuration and coordination of the organisational functions marketing, sales, R\&D, production, logistics, IT, finance, and customer service within and across business units and organisations to improve operative effectiveness and efficiency of the system and generate competitive advantages. SCM depends on organizations' network, since one single enterprise does not own the entire set of skills and resources required to deliver its value proposition. In turn, these networks' configurations are variable according to certain attributes (such as dynamic behaviour, level of trust between nodes, distribution of risks or benefits, geographical dispersion, etc.), to characteristics of each organisation representing the network node (such as strategy, position in the value chain, degree of influence, etc.), and also to product type (tangibility, customization, variability, etc.) (Taylor et al., 2001). Another fundamental issue is the type of collaboration between organizations, which vary depending on the level of formalisation, commitment and duration of relationship: simple market transition, noncontractual agreement, contractual agreement, joint venture, and integrated company (Jagdev and Thoben, 2001). This discussion is particularly relevant in the corporate sustainability context, since strong collaboration network tend to be crucial in terms of improving sustainability performance (MacCarthy and Jayarathne, 2011). 
Table 2. Literature overview SCM, developed from Burgess et al. (2006); Asgari et al. (2016).

\begin{tabular}{|c|c|c|}
\hline Most cited textbooks & Review articles SCM & Reviews Sustainable SCM \\
\hline (Chopra and Meindl, 2015) & (Croom, Romano, and Giannakis, 2000) & (Fleischmann et al. 1997) \\
\hline (Christopher, 2016) & (Rungtusanatham et al., 2003) & (Browne et al., 2005) \\
\hline (Simchi-Levi and Kaminsky, 2007) & (Sachan and Datta, 2005) & (Meade, Sarkis, and Presley, 2007) \\
\hline (Handfield and Jr. 1998) & (Kouvelis, Chambers, and Wang, 2009) & (Srivastava, 2007) \\
\hline \multicolumn{2}{|c|}{ (Bowersox, Closs, and Cooper, 2012)(Gupta, Verma, and Victorino, 2009) } & (Carter and Rogers, 2008) \\
\hline (Monczka et al., 2015) & (Burgess, Singh, and Koroglu, 2006) & (Seuring, Müller, and M??ller, 2008) \\
\hline (Weele, 2014) & (Storey et al., 2006) & $\begin{array}{l}\text { (Bekkering, Broekhuis, and Van Gemert, } \\
\text { 2009) }\end{array}$ \\
\hline (Shapiro, 2007) & $\begin{array}{l}\text { (Giunipero, Handfield, and Eltantawy } \\
\text { 2006) }\end{array}$ & ,(Ilgin and Gupta, 2009) \\
\hline \multirow[t]{11}{*}{ (Tayur and Ganeshan 1999) } & (Alfalla-Luque and Medina-López, 2009) & (Carter and Liane Easton, 2011) \\
\hline & (Daugherty, 2011) & (Sarkis, Zhu, and Lai, 2011) \\
\hline & (Seuring and Gold, 2012) & (Gimenez and Tachizawa, 2012) \\
\hline & (Chen and Paulraj, 2004) & (Abbasi and Nilsson, 2012) \\
\hline & (Giannakis and Croom, 2004) & (Ashby, Leat, and Hudson-Smith, 2012) \\
\hline & (Ho, Au, and Newton, 2002) & (Morgan and Gagnon, 2013) \\
\hline & (Lummus, Krumwiede, and Vokurka, 2001 & (Lin et al., 2014) \\
\hline & (Mentzer et al., 2001) & (Stindt and Sahamie, 2014) \\
\hline & (New 1997) & (Majid Eskandarpour et al., 2015) \\
\hline & (Skjoett-Larsen 1999) & (Fahimnia, Sarkis, and Davarzani, 2015) \\
\hline & (Larson and Halldorsson, 2002) & (Ntabe, Munson, and Santa-eulalia, 2014) \\
\hline
\end{tabular}

There are also narrower definitions in the literature, which usually focus functionally on purchasing and define SCM as the strategic selection of, collaboration with, and control of suppliers. While these definitions have advantages for operationalisation in practice and demarcation from other concepts in theory, we choose a rather comprehensive definition to allow for broad applicability of our discussion. Depending on the definition, SCM can be an important part or almost identical with the concept of the value chain (Porter, 2004) and value creation and delivery (Richardson, 2008). Therefore, it is an essential part of the business model of organisations (Knyphausen-Aufsess and Meinhardt, 2002; Richardson, 2008) and plays a crucial role in transforming it for the Circular Economy. Organizational networks are called to reassess how and where value is added, consumed and recovered (Barber, Beach, and Zolkiewski, 2012).

The differences in supply chains of conventional and circular business models stem from the necessary closing, slowing, and narrowing of material and energy flows (Bocken et al., 2016). As we have argued in Figure 2, we assume that CBMs achieve the best sustainability performance, if all elements of the business model are aligned to support these three functions 
(value proposition, value creation and delivery, and value capture (Richardson, 2008)). While there are already some reviews on sustainable and 'green' supply chains, like (Abbasi and Nilsson, 2012; Ashby, Leat, and Hudson-Smith, 2012; Carter and Liane Easton, 2011; Fahimnia, Sarkis, and Davarzani, 2015; Gimenez and Tachizawa, 2012; Majid Eskandarpour et al., 2015; Sarkis et al., 2011; Seuring et al., 2008; Srivastava, 2007) and the special issue in Journal of Cleaner Production (JCP, 16(15), 2008), the literature on supply chains for the Circular Economy is rather nascent, mostly referring to closed loop supply chains with relatively few reviews to date, like (Govindan et al., 2015; Daniel et al., 2009; Stindt and Sahamie, 2014) The existing literature on Circular Economyis incomplete, referring mainly to its implementations in China (including sometimes dubious academic approaches, like (Ying and Li-jun, 2012)), with one review in the context of Waste-to-Energy supply chains (Pan et al., 2014).

Based on this literature, we define Circular Supply Chain Management (CSCM) as the configuration and coordination of the organisational functions marketing, sales, $R \& D$, production, logistics, IT, finance, and customer service within and across business units and organisations to close, slow, intensify, narrow, and dematerialise material and energy loops to minimise resource input into and waste and emission leakage out of the system, improve its operative effectiveness and efficiency and generate competitive advantages.

Following the importance of the value chain for the business model and the need for alignment of all the business model's elements for optimal sustainability performance, it can be argued that CSCM aiming at fostering sustainable development should incorporate SBM characteristics. Thus, CSCM for sustainable development should comprise the creation of additional monetary and non-monetary value, a pro-active multiple stakeholder management, and a long-term perspective, as illustrated in Table 3.

Table 3. Comparison of SCM, CSCM and CSCM for sustainable development (SD)

\begin{tabular}{llll}
\hline & \multicolumn{1}{c}{ SCM } & \multicolumn{1}{c}{ CSCM } & \multicolumn{1}{c}{ CSCM for SD } \\
\hline Aim & $\begin{array}{l}\text { Operative effectiveness } \\
\text { and efficiency } \\
\text { Competitive advantages }\end{array}$ & $\begin{array}{l}\text { Operative effectiveness } \\
\text { and efficiency }\end{array}$ & $\begin{array}{l}\text { Operative effectiveness and } \\
\text { efficiency }\end{array}$ \\
& Competitive advantages & Competitive advantages
\end{tabular}


Minimising material and energy input

Minimising waste and emission leakage
Minimising material and energy input

Minimising waste and emission leakage

Social effectiveness (e.g. Intraand intergenerational equity, secure and meaningful employment, professional and personal development)

Environmental effectiveness (e.g. Land use, biodiversity, pollution, resource depletion)

Economic effectiveness (e.g. healthy ownership structures, financial independence, sustainable (VRIO) competitive advantage)

\begin{tabular}{llll}
\hline Means & $\begin{array}{l}\text { Configuration } \\
\text { organisational functions }\end{array}$ & $\begin{array}{l}\text { Configuration } \\
\text { organisational functions }\end{array}$ & $\begin{array}{l}\text { Configuration organisational } \\
\text { functions }\end{array}$ \\
$\begin{array}{l}\text { Coordination of } \\
\text { organisational functions }\end{array}$ & $\begin{array}{l}\text { Coordination of } \\
\text { organisational functions } \\
\text { Closing resource loops } \\
\text { Slowing resource loops }\end{array}$ & $\begin{array}{l}\text { Coordination of organisational } \\
\text { functions }\end{array}$ \\
& Narrowing resource loops & Slowing resource loops \\
& & $\begin{array}{l}\text { Narrowing resource loops } \\
\text { Creation of additional monetary } \\
\text { and non-monetary value }\end{array}$ \\
& & $\begin{array}{l}\text { Pro-active multiple stakeholder } \\
\text { management }\end{array}$ \\
& & Long-term perspective
\end{tabular}

\section{Research method}

The literature analysis provided a theoretical background for the conducted case studies. This research method was chosen given the exploratory characteristic of the research. Besides, case studies are also suitable for investigations on contemporary phenomenon (Yin, 2010) and provides in-depth understandings of unique set ups (Simmons, 2009), as is the situation for the present research. We followed the recommendations of Eisenhardt (1989) and Yin(2009).

Once the literature review was conducted, providing the main literature background, the next step was to choose the companies to be part of the research. A specific selection criterion was defined, as the research method based on case studies calls for defining a theoretical sampling (Eisenhardt and Graebner, 2007), rather than a statistically representative one. The main selection criteria was that the organization's business model had to be aligned with either closing, slowing, intensifying loops, narrowing loops and/or dematerialising loops. Four companies were selected for exploring business opportunities under the circular economy logic. Alpha's core idea is to provide remanufactured office furniture, using end of life goods 
to produce well-functioning products within an internal design solution. Meanwhile, Beta produces flat rolled aluminium with very high recycled content (significantly higher than others in the market). Gama designs and produces luxurious fashion accessories (such as purses and belts) from fire hoses and Delta provides a bike sharing service. The first three companies are from the United Kingdom, while the forth one is a Brazilian company. Beta is the only large company, while the others are medium and smaller companies, with less than 50 employees (Delta) and around 10 employees (Alpha and Gama). Despite different sectors and business models, each company chosen as case study represents a starting point for characterising elements and functions contributing to the Circular Economy.

Data collection was conducted mainly based on semi-structured interviews with key informants of the companies. Biases in the interviews and reporting were considered during data analysis, as pointed out by previous qualitative research on corporate sustainability. To mitigate this research limitation, interview data was complemented by published documents and companies' websites. Besides during interviews, concrete examples were asked to illustrate generic statements. Key informants were chosen given their involvement and general knowledge about each company's business model. Interviewees included the CEO and founder of Alpha, Gama and Delta, and the corporate sustainability manager of Beta. The interviews encompassed questions about the interviewees' description and perceptions according to the CBM of their respective companies. In particular, they were asked about the company's (1) value proposition in terms of economic, environmental and social value the firm aim at delivering; (2) creation and delivery system with focus on the role of the business in closing the loop of the product life cycle; and (3) value captured by the various stakeholders of each case study. The collected data were analysed qualitatively, according to aspects regarding sustainable development and circular economy.

\section{Research results analysis}

As previously indicated by Table 3, CSCM for SD encompasses traditional aims and means as SCM and as CSCM, with additional issues related to (1) social, environmental and economic goals, (2) pro-active multiple stakeholder management, (3) long-term perspective, and (4) closing, narrowing and slowing resource loops.

\subsection{Economic, environmental and social goals}

We initiated the data analysis by discussing social, environmental and economic goals of the case studies. To do so, a triangulated analysis was performed, including the case studies' declared mission and/or vision stated in their corporate websites, combined with the interviews. In order to maintain the companies' name confidential, the exact statements from the websites are not shown. All four of the organizations are for-profit organizations, as they aim at providing revenue to cover their costs and generate profit by selling their products and services. Regarding environmental goals, three of them explicitly seek to tackle environmental goals in reducing landfill, as declared in the respective websites. In particular, they foster the market for recycled (Beta and Gama) and remanufactured (Alpha) goods. When asked about the environmental impact of Delta, the company replied that they probably have a positive impact 
on carbon emission, but have not yet focused effort to calculate it. They believe that by enabling the possibility for people to cycle instead of using their cars to move around the city can has potential to compensate the emissions associated to their operations.

The explicit connection of the studied companies to social goals vary from one case to the other. Alpha's statement is clear and specific on their goals to create local jobs through remanufacturing. Delta's goal for society is also explicit, which is to integrate bicycles as an alternative for urban transportation. Meanwhile, Beta declares their commitment to customers, co-workers and local communities, without pointing out what specifically they intend to create to these stakeholders. Data from both interview and website statement indicates Beta's contribution to society in terms of technology innovation and development related to production process of sheets from recycled aluminium, as well as to the application and usage of aluminium sheets with high recycled content. In turn, Gama's statement is also not explicit in this regard and mentions a more intangible value, indicating how much society loses with materials going to landfill or incineration, in terms of quality, narrative and opportunity to do better.

\subsection{Pro-active multiple stakeholder management}

Another relevant aspect for CSCM and CBM is relates to a pro-active multiple stakeholder management. A summary of the stakeholders and the value created and delivered to each of them is shown in Table 4. It brings evidence that the organizations are having a proactive approach not only towards its shareholders, but also to other internal and external stakeholders. Alpha and Gama, for instance, explicitly mentioned their intention to contribute to practice for circular economy, serving as an example and to push partners and innovation to make their circular business viable. Besides, Beta saw the opportunity to reduce dependency of imports commodity-priced materials with high carbon emission and turned into heavy investments in new technology to produce quality aluminium sheets with high percentage of recycled material. Moreover, they also engaged in partnership with clients to develop technology applied to low carbon aluminium components and applications, e.g., towards actively enabling the market for low carbon products to grow.

Delta, on the other hand, saw from international market the opportunity to invest bike sharing, as one of the pioneers of this idea in its country (Brazil). It is worth noting that, what the cases have in common is the need to develop their consumer market, actively promoting awareness on the environmental and/or social value they aim to create and deliver. Development of a supply chain network that is able to collect used office furniture that would be in the end of life and to combine skills and infrastructure to remanufacture goods is also a challenge for Alpha. The company is engaged in developing these partners to enable their business to grow.

Table 4. Sustainable value captured by stakeholders.

\begin{tabular}{lllll}
\hline Stakeholder & Alpha & Beta & Gama & Delta \\
\hline
\end{tabular}




\begin{tabular}{|c|c|c|c|c|}
\hline $\begin{array}{l}\text { Shareholders/ } \\
\text { Investors }\end{array}$ & $\begin{array}{l}\text { Structurally lower cost } \\
\text { disruptive high } \\
\text { growth and } \\
\text { sustainable business }\end{array}$ & $\begin{array}{l}\text { Supply risk reduction, } \\
\text { longer term return }\end{array}$ & $\begin{array}{l}\text { Satisfaction of } \\
\text { business with } \\
\text { purpose }\end{array}$ & $\begin{array}{l}\text { Satisfaction and } \\
\text { motivation }\end{array}$ \\
\hline Employees & $\begin{array}{l}\text { Opportunity to work } \\
\text { for a company with } \\
\text { purpose }\end{array}$ & $\begin{array}{l}\text { Motivation towards } \\
\text { challenging targets for } \\
\text { increasing rate of } \\
\text { recycled content in the } \\
\text { product }\end{array}$ & $\begin{array}{l}\text { Satisfaction of } \\
\text { business with } \\
\text { purpose } \\
\text { Decent salary }\end{array}$ & $\begin{array}{l}\text { Satisfaction of } \\
\text { business with purpose }\end{array}$ \\
\hline Clients & $\begin{array}{l}\text { Quality and price } \\
\text { combination for } \\
\text { products and services, } \\
\text { wellness and } \\
\text { productivity (interior } \\
\text { design) }\end{array}$ & $\begin{array}{l}\text { Product quality } \\
\text { (independent from the } \\
\text { inputs for production) } \\
\text { Partnership with clients } \\
\text { for technology } \\
\text { development applied to } \\
\text { low carbon aluminium } \\
\text { components and } \\
\text { applications }\end{array}$ & $\begin{array}{l}\text { Purpose driven } \\
\text { products } \\
\text { Long-term } \\
\text { products (financial } \\
\text { return) }\end{array}$ & $\begin{array}{l}\text { Private sponsor for } \\
\text { bike sharing service: } \\
\text { brand value, relation } \\
\text { to local government }\end{array}$ \\
\hline Suppliers & $\begin{array}{l}\text { Chance to sell surplus } \\
\text { waste stock (used as } \\
\text { input for } \\
\text { remanufacturing } \\
\text { process) }\end{array}$ & $\begin{array}{l}\text { Development of } \\
\text { equipment suppliers to } \\
\text { address the technical } \\
\text { challenges of high } \\
\text { recycled content }\end{array}$ & $\begin{array}{l}\text { Close relationship } \\
\text { with suppliers of } \\
\text { materials (such as } \\
\text { fire-fighters } \\
\text { community) }\end{array}$ & $\begin{array}{l}\text { Income } \\
\text { Connection to the } \\
\text { business purpose }\end{array}$ \\
\hline Society & $\begin{array}{l}\text { Local semi-skilled } \\
\text { jobs, reduction of } \\
\text { supply risk, } \\
\text { demonstration of a } \\
\text { working circular } \\
\text { business }\end{array}$ & $\begin{array}{l}\text { Higher environmental } \\
\text { awareness } \\
\text { Engagement of local } \\
\text { organizations to collect } \\
\text { recycled material } \\
\text { Low carbon footprint } \\
\text { products (packaging) }\end{array}$ & $\begin{array}{l}\text { Transition to a } \\
\text { circular economy }\end{array}$ & $\begin{array}{l}\text { Environmental and } \\
\text { health awareness } \\
\text { Bike culture }\end{array}$ \\
\hline Environment & $\begin{array}{l}\text { Less burden on } \\
\text { landfill }\end{array}$ & $\begin{array}{l}\text { Reduction of carbon } \\
\text { emission throughout the } \\
\text { whole process }\end{array}$ & $\begin{array}{l}\text { Less burden on } \\
\text { landfill }\end{array}$ & $\begin{array}{l}\text { Low carbon additional } \\
\text { solution for urban } \\
\text { transportation }\end{array}$ \\
\hline Government & $\begin{array}{l}\text { Local semi-skilled } \\
\text { jobs, reduction of } \\
\text { supply risk, } \\
\text { demonstration of a } \\
\text { working circular } \\
\text { business }\end{array}$ & $\begin{array}{l}\text { Retaining local } \\
\text { production value (instead } \\
\text { of buying from abroad) }\end{array}$ & Taxes & Image before society \\
\hline
\end{tabular}

\subsection{Long-term perspective within short term actions}

Alpha is an office furniture remanufacturer, Beta is a high recycled content flat aluminium sheet manufacturer, Gama designs and produces luxurious fashion accessories from fire hoses, and Delta provides a bike sharing service. Regarding the long-term perspective, companies are pushed to account for future generations based on their decision of the present. The positive contribution of each case study in the long run was also discussed during interviews. For Alpha and Gama, as mentioned before, it is about building an economically viable business today to help disseminate the circular economy principles. Regarding Alpha, this is particularly in the office furniture business, for which it is fundamental that other organizations in logistics (direct and reverse) and production (remanufacturing) are able to provide infrastructure to other circular business. 
Gama, on the other hand, is interested in materials with high potential of usage, without the objective of closing specific material cycles. Although they started and are very strong with luxury accessories from fire-hoses, they also work with other materials, such as leather waste and parachute silk. Their intention is to awake on people the perception on the value of certain materials and on the possibility of having goods that last virtually never end in the landfill and can be used for many generations ahead. Beta's legacy to the long-term is aligned with its business decision on investing in technologies for low carbon aluminium goods and production process.

In turn, Delta aims to disseminate the culture of bike sharing as a day-to-day solution and not only for leisure to adults and children as users, and also to private and public organizations as business opportunity.

\subsection{Circular resource loops and guidelines for sustainable business models}

Regarding the companies' respective resource loops, interesting insights were also collected in the field. The circular business models presented by the case studies are aligned with the Butterfly diagram (Ellen-MacArthur-Foundation, 2013). Focusing on the right side of the diagram (the technical cycles), Alpha clearly contributes to the refurbish/remanufacture cycle, while Beta and Gama are examples of recycling business models. Yet, Delta is more aligned with the maintenance cycle, intensifying the use of their bicycles by internally designing and manufacturing a robust product that is easy repair. The CBM's value proposition together with requirements of a CSCM are summarized in Table 5.

Table 5. Towards circular business model and circular supply chain in the case studies. 


\begin{tabular}{|c|c|c|c|c|c|}
\hline $\begin{array}{l}\text { BM } \\
\text { type }\end{array}$ & Elements & Alpha & Beta & Gama & Delta \\
\hline \multirow[t]{5}{*}{ CBM } & Closing loops & $\begin{array}{l}\text { Development of } \\
\text { partners to provide } \\
\text { reverse logistics of } \\
\text { used furniture and } \\
\text { remanufacturing }\end{array}$ & $\begin{array}{l}\text { High investment on } \\
\text { R\&D for product } \\
\text { development }\end{array}$ & $\begin{array}{l}\text { Low waste in } \\
\text { the production } \\
\text { stage }\end{array}$ & \\
\hline & Slowing loops & & & \multirow[t]{4}{*}{$\begin{array}{l}\text { Product design } \\
\text { based on long } \\
\text { usage stage }\end{array}$} & $\begin{array}{l}\text { Internal product } \\
\text { development and } \\
\text { bike assembly to } \\
\text { ensure long usage } \\
\text { stage and } \\
\text { facilitated } \\
\text { maintenance }\end{array}$ \\
\hline & $\begin{array}{l}\text { Intensifying } \\
\text { loops }\end{array}$ & & & & $\begin{array}{l}\text { Bike sharing } \\
\text { intensifies use } \\
\text { phase }\end{array}$ \\
\hline & $\begin{array}{l}\text { Narrowing } \\
\text { loops }\end{array}$ & & \multirow[t]{2}{*}{$\begin{array}{l}\text { Partnership with } \\
\text { clients interested in } \\
\text { low carbon } \\
\text { solutions }\end{array}$} & & \\
\hline & $\begin{array}{l}\text { Dematerialising } \\
\text { loops }\end{array}$ & & & & $\begin{array}{l}\text { Rent service } \\
\text { instead of product } \\
\text { ownership }\end{array}$ \\
\hline \multirow[t]{3}{*}{ SBM } & $\begin{array}{l}\text { Creation of } \\
\text { sustainable } \\
\text { value: }\end{array}$ & $\begin{array}{l}\text { Interior design } \\
\text { solution, combining } \\
\text { remanufactured and } \\
\text { new office furniture }\end{array}$ & $\begin{array}{l}\text { Flat rolled } \\
\text { aluminium with } \\
\text { very high recycled } \\
\text { content }\end{array}$ & $\begin{array}{l}\text { Luxurious } \\
\text { fashion } \\
\text { accessories } \\
\text { (such as purses } \\
\text { and belts) from } \\
\text { fire hoses }\end{array}$ & $\begin{array}{l}\text { Service for } \\
\text { individual urban } \\
\text { transportation } \\
\text { (bike sharing) }\end{array}$ \\
\hline & $\begin{array}{l}\text { Pro-active } \\
\text { multiple } \\
\text { stakeholder }\end{array}$ & $\begin{array}{l}\text { Pushing the supply } \\
\text { chain to develop } \\
\text { towards circular } \\
\text { economy } \\
\text { Promoting the culture } \\
\text { of remanufactured } \\
\text { goods }\end{array}$ & $\begin{array}{l}\text { Pushing technology } \\
\text { boundaries for low } \\
\text { carbon aluminium } \\
\text { goods and } \\
\text { production process }\end{array}$ & $\begin{array}{l}\text { Pushing the } \\
\text { supply chain to } \\
\text { develop } \\
\text { towards circular } \\
\text { economy } \\
\text { Promotion of } \\
\text { sustainable } \\
\text { consumption }\end{array}$ & $\begin{array}{l}\text { Dissemination of } \\
\text { the culture of bike } \\
\text { sharing as } \\
\text { transportation for } \\
\text { short distances }\end{array}$ \\
\hline & $\begin{array}{l}\text { Long-term } \\
\text { perspective }\end{array}$ & $\begin{array}{l}\text { Urgency to action to } \\
\text { change towards } \\
\text { circular economy }\end{array}$ & $\begin{array}{l}\text { Need to develop } \\
\text { alternative } \\
\text { materials to reduce } \\
\text { dependency on } \\
\text { imports and } \\
\text { commodity prices }\end{array}$ & $\begin{array}{l}\text { Urgency to } \\
\text { action to } \\
\text { change towards } \\
\text { circular } \\
\text { economy }\end{array}$ & $\begin{array}{l}\text { Need for more } \\
\text { efficient ways for } \\
\text { urban } \\
\text { transportation }\end{array}$ \\
\hline
\end{tabular}




\section{Discussions and framework proposal}

Combining the analysis of the literature and data from case studies, a framework is proposed, combining the discussions on sustainable development, circular economy, circular supply chain management and circular business models in practice (Figure 3). In doing so, we try to bring initial discussion on how these constructs are interconnected. On the left side, the framework reinforces the dependency between a single organization, a specific CBM, and its value network, as a circular supply chain. In this sense, the research corroborates with previous arguments on the contribution of CSCM to closing, narrowing and slowing the loop (Bocken et al., 2017), complementing this view with intensifying and dematerialising efforts, as discussed in Section 4.4 and illustrated in Table 5. Empirical evidence from performance case studies reinforces the crucial role of network infrastructure and capabilities to enable CBM operations. For instance, Delta realized the key role of using a bicycle that was durable and relatively easy to perform maintenance and decided to switch is operations from buying to assembling their own bicycles.

Furthermore, the proposed framework also indicates that the previous arguments depend on the following conditions (aims and means) for circularity and for sustainability: economic, environmental and social goals, proactive stakeholder management, long-term perspective. Each business condition was previously discussed in the literature (Geissdoerfer et al., 2017b) and the performed research initially addresses this issue, as the case studies presented in Sections 4.1, 4.2 and 4.3 bring empirical evidence on the relevance of these conditions. These aspects reinforces that the triple bottom line approach focused on a sustainability based on three pillars: economic, environmental and social ones (Elkington, 1997b) is relevant, but not sufficient for CBM's and SBM's. A broad and proactive approach on stakeholders and longterm perspective to complement short termed ones are also crucial factors for successful sustainable businesses.

Previous knowledge has already pointed out initial discussions on the relation between sustainable development and circular economy (Geissdoerfer et al., 2017a). In this sense, our paper adds to this by bringing empirical evidence on the relationship between these perspectives, as the present research explores this link by arguing the three conditions for CBM to address challenges for Circular Economy and, at the same time, for Sustainable Development. The connection between these perspectives is still open for discussion. On the one hand, one can argue that Circular Economy is one possible way, amongst others, to reach Sustainable Development. On the other hand, Sustainable Development is a concept that is so broad and intangible that may lose meaning, while Circular Economy could became a more tangible way to organize society and economy. In summary, our research seeks to contribute at some extend to this discussion, by illustrating an overlapping area between the concepts, but understands the need for further and deeper arguments. This overlapping area represents arguments from the case studies that, while the tackle the three conditions for sustainability using a business model based on closing, slowing, narrowing, intensifying and/or dematerialising. 


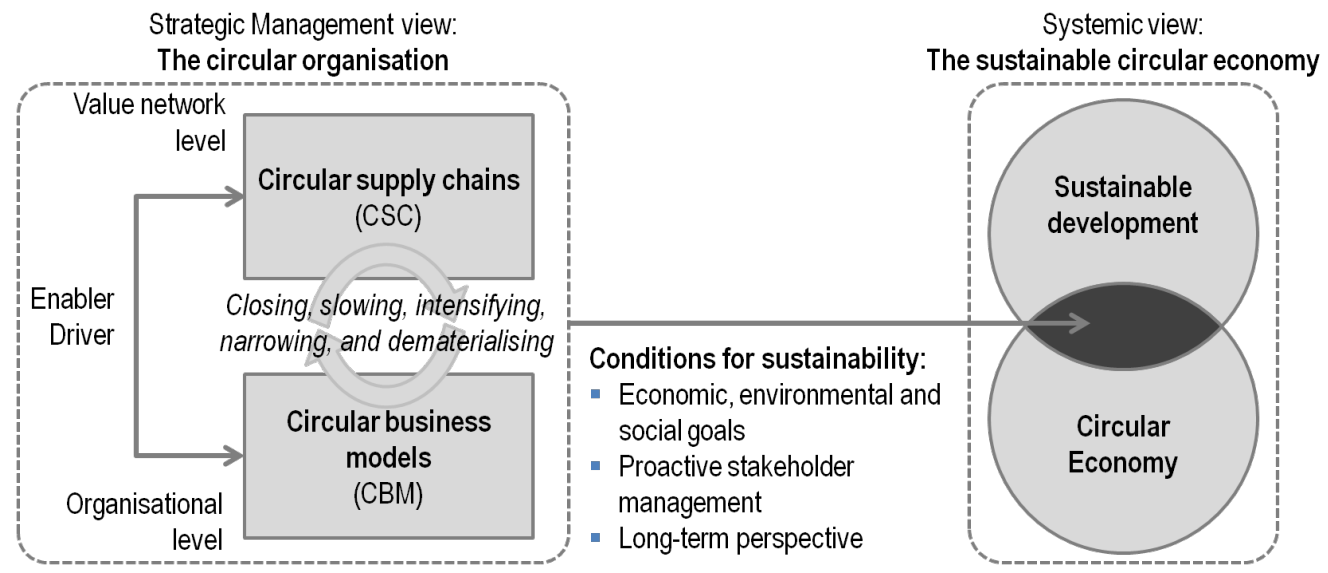

Figure 3. Proposed framework.

\section{Conclusions and outlook}

The present research contributes to the literature by proposing an integrated framework on CBM and CSCM built on theory and practice, discussing their interrelation and the contribution to the dimensions of sustainability. To address this, four case studies were presented: Alpha, an office furniture remanufacturer, Beta, a high recycled content aluminium sheet producer, Gamma, a recycled luxury accessories manufacturer, and Delta, a bike-sharing company.

All four case studies present circularity aspects incorporated into their business models and supply chains. The findings confirm previous research on SBMs derived from creating value from waste (Bocken et al., 2014) and evidence for CBM and CSCM elements was found. This includes products designed and manufactured from disposed materials, partnership building for reverse logistics and efforts to provoke system change by communicating and collaborating for the Circular Economy. This reinforces previous theoretical researches that indicated the need not only for technical innovations (e.g., in terms of material flows), but also for social innovations (e.g. in terms of changes in consumer behaviour), such as discussed in Winans et al. (2017).

However, the cases studied still face challenges in changing the paradigm from linear to circular, especially regarding adaptations needed in the companies' supply chains and in purchasing processes of customers. Empirical data show alignment between CBM and consequently CSCM to sustainable development challenges. As proposed by the framework showed in Figure 3, CBM, aligned with circular supply chain, can contribute to sustainable development by promoting economic, environmental and social goals; pro-actively managing stakeholders; including a long-term perspective; and closing, slowing, intensifying, narrowing and dematerializing resource loops. The resource loops for circularity were previously pointed out by the literature (Bocken, Bakker, and Pauw, 2016). Our framework complements this view by adding explicitly initiatives on intensifying and dematerializing loops for circular economy. 
This paper brings implications to practice by presenting different CBM and discussing the main challenges faced in practice. The case studied present similarities and contrasts. For example, while Alpha is a small company, with local action, born with a circularity mind-set and the explicit purpose to contribute to sustainable development, Beta is a large globally present organisation and enlarges the amount of recycled material into its product mainly to compensate for uncertainty in resource purchasing. Despite these differences, all the case companies' business models depend on changing consumers and suppliers' behaviour, since CBM and CSCM demand a systemic paradigm shift. For instance, the companies' customers' product quality perception from remanufactured or recycled material tended to be lower than for traditional goods, resulting in lower realisable prices. This is despite the products' high quality requirements and comparatively little advantages in their cost structure.

The main limitations in our research encompass, first and foremost, the limited number of case studies and data collection based mostly on only one interview for each case study. However, the interviews were triangulated with publicly available documents to mitigate this. Interviews with other stakeholders from the supply chain to complement data collection can be an interesting future follow-up study to complement the present one. All in all, this research is to be seen as among the first steps in evaluating whether 'going circular' really makes businesses and their supply chains more sustainable. A more systematic assessment of their contribution to sustainable development goals will be desirable to confirm and complements these first steps.

\section{Acknowledgements}

This work was supported by the Brazilian institutes: National Counsel of Technological and Scientific Development (CNPq) and Coordination for the Improvement of Higher Education Personnel (CAPES).

\section{References}

Abbasi, Maisam, and Fredrik Nilsson., 2012. "Themes and Challenges in Making Supply Chains Environmentally Sustainable." Edited by Richard Wilding. Supply Chain Management: An International Journal $17 \quad$ (5): 517-30. doi:10.1108/13598541211258582.

Alfalla-Luque, Rafaela, and Carmen Medina-López., 2009. "Supply Chain Management: Unheard of in the 1970s, Core to Today's Company." Business History 51 (2):, 202-21. doi:10.1080/00076790902726558.

Asgari, Nasrin, Ehsan Nikbakhsh, Alex Hill, and Reza Zanjirani Farahani., 2016. "Supply Chain Management 1982-2015: A Review." IMA Journal of Management Mathematics 27 (3): 353-79. doi:10.1093/imaman/dpw004.

Ashby, Alison, Mike Leat, and Melanie Hudson- Smith., 2012. "Making Connections: A Review of Supply Chain Management and Sustainability Literature." Edited by Richard Wilding. Supply Chain Management: An International Journal 17 (5): 497-516. doi:10.1108/13598541211258573.

Bakker, C. A., M.C. den Hollander, E. van Hinte;, and Yvo Zljlstra., 2014. Products That Last - Product Design for Circular Business Models. Delft: TU Delft Library. 
Barber, Kevin D., Roger Beach, and Judy Zolkiewski., 2012. "Environmental Sustainability: A Value Cycle Research Agenda." Production Planning \& Control 23 (2-3): 105-19. doi:10.1080/09537287.2011.591621.

Bekkering, J, A A Broekhuis, and W J T Van Gemert., 2009. "Optimisation of a Green Gas Supply Chain - A Review." Bioresource Technology 101: 450-56. doi:10.1016/j.biortech.2009.08.106.

Benyus, Janine M., 2002. Biomimicry. New York: Harper Perennial.

Bocken, Nancy M. P., Conny Bakker, and Ingrid De Pauw., 2016. "Product Design and Business Model Strategies for a Circular Economy." Journal of Industrial and Production Engineering 1015 (0):, 20. doi:10.1080/21681015.2016.1172124.

Bocken, Nancy M. P., Ingrid de Pauw, Conny Bakker, and Bram van der Grinten., 2016. "Product Design and Business Model Strategies for a Circular Economy." Journal of Industrial and Production Engineering 33 (5). Taylor \& Francis: 308-20. doi:10.1080/21681015.2016.1172124.

Bowersox, Donald, David Closs, and M. Bixby Cooper., 2012. Supply Chain Logistics Management. 4th ed. London: McGraw-Hill.

Browne, Michael, Christophe Rizet, Stephen Anderson, Julian Allen, and Basile Keïta., 2005. "Life Cycle Assessment in the Supply Chain: A Review and Case Study." Transport Reviews 25 (6). Routledge: 761-82. doi:10.1080/01441640500360993.

Burgess, Kevin, Prakash J. Singh, and Rana Koroglu., 2006. "Supply Chain Management: A Structured Literature Review and Implications for Future Research." Edited by Paul D. Cousins. Co- Editors: Benn Lawson. International Journal of Operations \& Production Management 26 (7): 703-29. doi:10.1108/01443570610672202.

Carter, Craig R., and P. Liane Easton., 2011. "Sustainable Supply Chain Management: Evolution and Future Directions." Edited by Michael Crum. International Journal of Physical Distribution \& Logistics Management $41 \quad$ (1): 46-62. doi:10.1108/09600031111101420.

Carter, Craig R., and Dale S. Rogers., 2008. "A Framework of Sustainable Supply Chain Management: Moving toward New Theory." International Journal of Physical Distribution \& Logistics Management 38 (5): 360-87. doi:10.1108/09600030810882816.

Chen, Injazz J, and Antony Paulraj., 2004. "Towards a Theory of Supply Chain Management: The Constructs and Measurements." Journal of Operations Management 22: 119-50. doi:10.1016/j.jom.2003.12.007.

Chesbrough, H, and RS Rosenbloom., 2002. "The Role of the Business Model in Capturing Value from Innovation: Evidence from Xerox Corporation's Technology Spin- off Companies." Industrial and Corporate ....

Chopra, Sunil, and Peter Meindl., 2015. Supply Chain Management: Strategy, Planning, and Operation. 6th ed. London: Pearson.

Christopher, M., 2016. Logistics and Supply Chain Management. 5th ed. London: Financial Times/Pearson Education.

Commoner, Barry. 1971. The Closing Circle: Nature, Man, and Technology. New York: Knopf.

Cooper, Martha C., and Lisa M. Ellram. 1993. "Characteristics of Supply Chain Management and the Implications for Purchasing and Logistics Strategy." The International Journal of Logistics Management 4 (2): 13-24. doi:10.1108/09574099310804957.

Croom, Simon, Pietro Romano, and Mihalis Giannakis., 2000. "Supply Chain Management: An Analytical Framework for Critical Literature Review." European Journal of Purchasing \& Supply Management 6 (1): 67-83. doi:10.1016/S0969-7012(99)00030-1.

Daugherty, Patricia J., 2011. "Review of Logistics and Supply Chain Relationship Literature and Suggested Research Agenda." Edited by Michael Crum. International Journal of 
Physical Distribution \& Logistics Management $41 \quad$ (1): 16-31. doi:10.1108/09600031111101402.

Doleski, O. D., 2015. Integrated Business Model: Applying the St. Gallen Management Concept to Business Models.

Eisenhardt, Kathleen M. 1989. "Building Theories from Case Study Research." The Academy of Management Review 14 (4): 532. doi:10.2307/258557.

Elkington, J. 1997. Cannibals With Forks: The Triple Bottom Line of 21st Century Business. London: John Wiley and Sons.

Ellen-MacArthur-Foundation., 2013. "Towards the Circular Economy: Economyc and Business Rationale for Accelerated Transition." Vol. 1. doi:10.1162/108819806775545321.

European_Commission., 2014. "Towards a Circular Economy: A Zero Waste Programme for Europe. Communication from the Commission to the European Parliament, the Council, the European Economic and Social Committee and the Committee of the Regions." https://scholar.google.co.uk/scholar?hl=en\&q=European+Commission\%2C+2014.+Tow ards $+\mathrm{a}+$ circular+economy $\% 3 \mathrm{~A}+\mathrm{A}+$ zero + waste + programme + for + Europe. $\& b \operatorname{bth}=\&$ as_s $\mathrm{dt}=1 \% 2 \mathrm{C} 5 \&$ as_sdtp $=\# 0$.

European Commission., 2014. "Towards a Circular Economy: A Zero Waste Programme for Europe." Communication from the Commission to the European Parliament, the Council, the European Economic and Social Committee and the Committee of the Regions.

Evans, Steve., 2009. Towards a Sustainable Industrial System: With Recommendations for Education, Research, Industry and Policy. Cambridge: University of Cambridge.

Evans, Steve, Padmakshi Rana, and Samuel W Short., 2014. "Final Set of Tools and Methods That Enable Analysis of Future Oriented, Novel, Sustainable, Value Adding Buisness Models and Value-Networks." EU SustainValue Project Deliverable 2.6.

Fahimnia, Behnam, Joseph Sarkis, and Hoda Davarzani., 2015. "Green Supply Chain Management: A Review and Bibliometric Analysis." International Journal of Production Economics 162 (April): 101-14. doi:10.1016/j.ijpe.2015.01.003.

Fleischmann, Moritz, Jacqueline M. Bloemhof-Ruwaard, Rommert Dekker, Erwin van der Laan, Jo A.E.E. van Nunen, and Luk N. Van Wassenhove. 1997. "Quantitative Models for Reverse Logistics: A Review." European Journal of Operational Research 103 (1). North-Holland: 1-17. doi:10.1016/S0377-2217(97)00230-0.

Geissdoerfer, Martin, Nancy Maria Petronella Bocken, and Erik Jan Hultink., 2016. "Design Thinking to Enhance the Sustainable Business Modelling Process." Journal of Cleaner Production 135: 1218-32. doi:10.1016/j.jclepro.2016.07.020.

Geissdoerfer, Martin, Paulo Savaget, Nancy M.P. Bocken, and Erik Jan Hultink., 2017a "The Circular Economy - A new sustainability paradigm?" Journal of Cleaner Production 143: 757-768. doi:10.1016/j.jclepro.2016.12.048

Geissdoerfer, Martin, Paulo Savaget, and Steve Evans., 2017b. "The Cambridge Business Model Innovation Process." Procedia Manufacturing 8: 262-269. doi:10.1016/j.promfg.2017.02.033.

Geissdoerfer, Martin, Doroteya Vladimirova, and Steve Evans. under review "Sustainable Business Model Innovation: A Review." Journal of Cleaner Production

Giannakis, Mihalis, and Simon R Croom., 2004. "Toward the Development of a Supply Chain Management Paradigm: A Conceptual Framework." The Journal of Supply Chain Management 40 (2): 27-37. doi:10.1111/j.1745-493X.2004.tb00167.x.

Gimenez, Cristina, and Elcio M. Tachizawa., 2012. "Extending Sustainability to Suppliers: A Systematic Literature Review." Edited by Richard Wilding. Supply Chain Management: An International Journal 17 (5): 531-43. doi:10.1108/13598541211258591.

Giunipero, Larry, Robert B. Handfield, and Reham Eltantawy., 2006. "Supply Management's 
Evolution: Key Skill Sets for the Supply Manager of the Future." Edited by Paul D. Cousins. International Journal of Operations \& Production Management 26 (7): 822-44. doi:10.1108/01443570610672257.

Govindan, Kannan, Hamed Soleimani, and Devika Kannan., 2015. "Reverse Logistics and Closed-Loop Supply Chain: A Comprehensive Review to Explore the Future." European Journal of Operational Research 240 (3): 603-26. doi:10.1016/j.ejor.2014.07.012.

Graedel, T. E., and Braden R. Allenby. 1995. Industrial Ecology. Englewood Cliffs, N.J: Prentice Hall.

Gupta, Sushil, Rohit Verma, and Liana Victorino., 2009. "Empirical Research Published in Production and Operations Management (1992-2005): Trends and Future Research Directions." Production and Operations Management 15 (3): 432-48. doi:10.1111/j.1937-5956.2006.tb00256.x.

Handfield, Robert B., and Ernest L. Nichols Jr. 1998. Introduction to Supply Chain Management. London: Pearson.

Ho, Danny C. K., K. F. Au, and Edward Newton., 2002. "Empirical Research on Supply Chain Management: A Critical Review and Recommendations." International Journal of Production Research 40 (17): 4415-30. doi:10.1080/00207540210157204.

Homrich, A.S., Galvão, G., Abadia, L.G., Carvalho, M.M., 2017. The Circular Economy Umbrella: Trends and Gaps on Integrating Pathways. J. Clean. Prod. 175. doi:10.1016/j.jclepro.2017.11.064

Ilgin, Mehmet Ali, and Surendra M Gupta., 2009. "Environmentally Conscious Manufacturing and Product Recovery (ECMPRO): A Review of the State of the Art." Journal of Environmental Management 91: 563-91. doi:10.1016/j.jenvman.2009.09.037.

Jagdev, H S, and K Thoben., 2001. "Anatomy of Enterprise Collaborations." Production Planning \& Control 12 (5): 437-51. doi:10.1080/0953728011004267.

Kauffman, Ralph G., 2002. "Supply M Anagement: What's in a Name? Or, Do We Know Who We Are?" The Journal of Supply Chain Management 38 (4). Blackwell Publishing Ltd: 46-50. doi:10.1111/j.1745-493X.2002.tb00142.x.

Knyphausen-Aufsess, D Zu, and Y Meinhardt., 2002. "Revisiting Strategy: Ein Ansatz Zur Systematisierung von Geschäftsmodellen." In Zukünftige Geschäftsmodelle, edited by Thomas; Bieger, Nils; Bickhoff, Rolf; Caspers, Dodo zu Knyphausen-Aufseß; and Kurt Reding. Berlin, Heidelberg: Springer.

Kouvelis, Panos, Chester Chambers, and Haiyan Wang., 2009. "Supply Chain Management Research and Production and Operations Management: Review, Trends, and Opportunities." Production and Operations Management 15 (3): 449-69. doi:10.1111/j.1937-5956.2006.tb00257.x.

Larson, Paul D., and Arni Halldorsson., 2002. "What Is SCM? And, Where Is It?" The Journal of Supply Chain Management 38 (4): 36-44. doi:10.1111/j.1745-493X.2002.tb00141.x.

Lin, Canhong, K L Choy, G T S Ho, S H Chung, and H Y Lam., 2014. "Survey of Green Vehicle Routing Problem: Past and Future Trends." Expert Systems With Applications 41: 1118-38. doi:10.1016/j.eswa.2013.07.107.

Lozano, Rodrigo., 2008. "Envisioning Sustainability Three-Dimensionally." Journal of Cleaner Production 16 (17): 1838-46. doi:10.1016/j.jclepro.2008.02.008.

Lummus, Rhonda R., Dennis W. Krumwiede, and Robert J. Vokurka., 2001. "The Relationship of Logistics to Supply Chain Management: Developing a Common Industry Definition.” Industrial Management \& Data Systems $101 \quad$ (8): 426-32. doi:10.1108/02635570110406730.

Lyle, John Tillman. 1994. Regenerative Design for Sustainable Development. New York: John Wiley \& Sons.

MacCarthy, B.L., and P.G.S.a. Jayarathne., 2011. "Sustainable Collaborative Supply Networks 
in the International Clothing Industry: A Comparative Analysis of Two Retailers." Production Planning \& Control 23 (4): 252-68. doi:10.1080/09537287.2011.627655.

Majid Eskandarpour, \$, Pierre Dejax, Joe Miemczyk, and Olivier Péton., 2015. "Sustainable Supply Chain Network Design: An Optimization-Oriented Review." Omega 54: 11-32. doi:10.1016/j.omega.2015.01.006.

McDonough, William, and Michael Braungart., 2002. Cradle to Cradle: Remaking the Way We Make Things. New York: North Point Press.

Meade, Laura, Joseph Sarkis, and Adrien Presley., 2007. "The Theory and Practice of Reverse Logistics.” International Journal of Logistics Systems and Management 3 (1): 56-84. doi:10.1504/IJLSM.2007.012070.

Meadows, Donella H., Dennis L. Meadows, Jorgen Randers, and William W. Behrens-III. 1972. The Limits to Growth: A Report for the Club of Rome's Project on the Predicament of Mankind. 5th ed. New York: Universe Books.

Meadows, Donella H., Jorgen Randers, and Dennis Meadows., 2004. Limits to Growth: The 30-Year Update. 1st ed. White River Junction: Chelsea Green Publishing.

Mentzer, John T., William DeWitt, James S. Keebler, Soonhong Min, Nancy W. Nix, Carlo D. Smith, and Zach G. Zacharia., 2001. "DEFINING SUPPLY CHAIN MANAGEMENT." Journal of Business Logistics 22 (2). Blackwell Publishing Ltd: 1-25. doi:10.1002/j.21581592.2001.tb00001.x.

Monczka, Robert M., Robert B. Handfield, Larry C. Giunipero, and James L. Patterson., 2015. Purchasing and Supply Chain Management. 6th ed. Boston: Cengage Learning.

Morgan, Shona D., and Roger J. Gagnon., 2013. "A Systematic Literature Review of Remanufacturing Scheduling." International Journal of Production Research 51 (16): 4853-79. doi:10.1080/00207543.2013.774491.

New, Stephen J. 1997. "The Scope of Supply Chain Management Research." Supply Chain Management: An International Journal 2 (1): 15-22. doi:10.1108/13598549710156321.

Nidumolu, Ram, C K Prahalad, and M R Rangaswami., 2009. "Why Sustainability Is Now the Key Driver of Innovation.” Harvard Business Review 87 (9): 56-64.

Ntabe, Eric N, Alison D Munson, and Luis Antonio De Santa-eulalia., 2014. "A Systematic Literature Review of the Supply Chain Operations Reference ( SCOR ) Model Application with Special Attention to Environmental Issues A Systematic Literature Review of the Supply Chain Operations Reference ( SCOR ) Model Application with Speci." International Journal of Production Economics 169: 310-32.

Osterwalder, A, and Y Pigneur., 2013. Business Model Generation: A Handbook for Visionaries, Game Changers, and Challengers.

Pan, Shu Yuan, Michael Alex Du, I. Te Huang, I. Hung Liu, E. E. Chang, and Pen Chi Chiang., 2014. "Strategies on Implementation of Waste-to-Energy (WTE) Supply Chain for Circular Economy System: A Review." Journal of Cleaner Production 108. Elsevier Ltd: 409-21. doi:10.1016/j.jclepro.2015.06.124.

Pauli, Gunter A., 2010. The Blue Economy: 10 Years, 100 Innovations, 100 Million Jobs. Taos, NM: Paradigm Publications.

Porter, Michael E., 2004. Competitive Advantage. New York: Free Press.

Porter, Michael E, and Mark R Kramer., 2011. "Creating Shared Value." JOUR. Harvard Business Review 89 (1/2): 62-77.

Richardson, James., 2008. "The Business Model: An Integrative Framework for Strategy Execution." Strategic Change 17 (5-6): 133-44. doi:10.1002/jsc.821 M4 - Citavi.

Ross, DF. 1998. Competing through Supply Chain Management: Creating Market-Winning Strategies through Supply Chain Partnerships. New York: Chapmann and Hall.

Rungtusanatham, M.Johnny, Thomas Y Choi, David G Hollingworth, Zhaohui Wu, and Cipriano Forza., 2003. "Survey Research in Operations Management: Historical 
Analyses." Journal of Operations Management. Vol. 21. doi:10.1016/S02726963(03)00020-2.

Sachan, Amit, and Subhash Datta., 2005. "Review of Supply Chain Management and Logistics Research.” International Journal of Physical Distribution \& Logistics Management 35 (9): 664-705. doi:10.1108/09600030510632032.

Sarkis, Joseph, Qinghua Zhu, and Kee-Hung Lai., 2011. "An Organizational Theoretic Review of Green Supply Chain Management Literature." Intern. Journal of Production Economics 130: 1-15. doi:10.1016/j.ijpe.2010.11.010.

Seuring, Stefan, and Stefan Gold., 2012. "Conducting Content Analysis Based Literature Reviews in Supply Chain Management." Edited by Richard Wilding. Supply Chain Management: An International Journal $17 \quad$ (5): 544-55. doi:10.1108/13598541211258609.

Seuring, Stefan, Martin Müller, and Martin M??1ler., 2008. "From a Literature Review to a Conceptual Framework for Sustainable Supply Chain Management." Journal of Cleaner Production 16 (15): 1699-1710. doi:10.1016/j.jclepro.2008.04.020.

Shapiro, Jeremy F., 2007. Modeling the Supply Chain. Belmont: Thomson Learning.

Simchi-Levi, David, and Philip Kaminsky., 2007. Designing and Managing the Supply Chain: Concepts, Strategies, and Case Studies. 3rd ed. London: McGraw- Hill.

Simmons, Helen., 2009. Case Study Research in Practice. London: SAGE Publications Ltd.

Skjoett-Larsen, Tage. 1999. "Supply Chain Management: A New Challenge for Researchers and Managers in Logistics." The International Journal of Logistics Management. doi:10.1108/09574099910805987.

Srivastava, Samir K., 2007. "Green Supply-Chain Management: A State-of-the-Art Literature Review." International Journal of Management Reviews 9 (1): 53-80. doi:10.1111/j.1468-2370.2007.00202.x.

Stadtler, Hartmut, Christoph Kilger, and Herbert Meyr., 2015. Supply Chain Management and Advanced Planning: Concepts, Models, Software, and Case Studies. Berlin, Heidelberg: Springer.

Stahel, Walter., 2010. The Performance Economy. Basingstoke, New York: Palgrave MacMillan.

Stindt, Dennis, and Ramin Sahamie., 2014. "Review of Research on Closed Loop Supply Chain Management in the Process Industry." Flexible Services and Manufacturing Journal 26 (1-2): 268-93. doi:10.1007/s10696-012-9137-4.

Storey, John, Caroline Emberson, Janet Godsell, and Alan Harrison., 2006. "Supply Chain Management: Theory, Practice and Future Challenges." Edited by Paul D. Cousins Coeditors: Benn Lawson. International Journal of Operations \& Production Management 26 (7): 754-74. doi:10.1108/01443570610672220.

Stubbs, W., and C. Cocklin., 2008. "Conceptualizing a 'Sustainability Business Model." Organization \& Environment 21: 103-27. doi:10.1177/1086026608318042.

Taylor, Publisher, K Thoben, and H S Jagdev., 2001. "Typological Issues in Enterprise Networks." Production 12 (5): 421-36. doi:10.1080/0953728011004266.

Tayur, Sridhar, and Ram Ganeshan. 1999. Quantitative Models for Supply Chain Management. Boston: Kluwer Academic.

United Nations., 2015. "Global Sustainable Development Report.” Lowe-Martin.

V. Daniel R. Guide Jr., and Luk N. Van Wassenhove., 2009. "OR FORUM-The Evolution of Closed-Loop Supply Chain Research.” Operations Research 57 (1): 10-18. doi:10.1287/opre.1080.0628.

WCED. 1987. "Report of the World Commission on Environment and Development: Our Common Future Acronyms and Note on Terminology Chairman' S Foreword." Oxford University Press, Oxford. 
Webster, Ken., 2015. The Circular Economy: A Wealth of Flows. Isle of Wight: Ellen MacArthur Foundation.

Weele, Arjan Van., 2014. Purchasing and Supply Chain Management: Analysis, Strategy, Planning and Practice. Boston: Cengage Learning.

Winans, K., Kendall, A., Deng, H., 2017. The history and current applications of the circular economy concept. Renew. Sustain. Energy Rev. 68, 825-833. doi:10.1016/j.rser.2016.09.123

$\mathrm{Wu}$, Zhaohui, and Mark Pagell., 2011. "Balancing Priorities: Decision-Making in Sustainable Supply Chain Management." Journal of Operations Management 29 (6). Elsevier B.V.: 577-90. doi:10.1016/j.jom.2010.10.001.

Yang, M., S. Evans, D. Vladimirova, and P. Rana., 2016. "Value Uncaptured Perspective for Sustainable Business Model Innovation." Journal of Cleaner Production in press: 1-11. doi:10.1016/j.jclepro.2016.07.102.

Yin, Robert K., 2009. Case Study Research: Design and Methods. Essential Guide to Qualitative Methods in Organizational Research. Vol. 5. doi:10.1097/FCH.0b013e31822dda9e.

Yin, Robert K., 2010. Estudo de Caso: Planejamento E Métodos. 4th ed. Porto Alegre: Bookman.

Ying, Jiang, and Zhou Li-jun., 2012. "Study on Green Supply Chain Management Based on Circular Economy." Physics Procedia 25. Elsevier Srl: 1682-88. doi:10.1016/j.phpro.2012.03.295.

Zhu, Qinghua, and Joseph Sarkis., 2004. "Relationships Between Operational Practices and Performance Among Early Adopters of Green Supply Chain Management Practices in Chinese Manufacturing Enterprises." Journal of Operations Management 22 (3): 265-89. doi:10.1016/j.jom.2004.01.005. 